\title{
Development of Innovative Course Outcomes : using S.M.A.R.T. Goals
}

\section{Kamal Mistry, Prathamesh Churi}

\begin{abstract}
Build layer of OBEE architecture forms an innovative way to towards development of course outcomes from lesson outcomes [4]. The process of development of course outcomes is crucial and time-consuming without appropriate guidance and support. This paper, therefore, provides guidelines /rules towards the development of outcomes according to the OBEE architecture. The paper also suggests a sample Course outcomes taking one engineering course as a case study. The phenomenon of making course outcome is based on a SMART approach. The process also suggests that we should involve industry domain experts and Alumni students which give a proper academic and practically oriented shape to the documented course outcomes. As a result, the entire $O B E E$ process becomes smoother and functional in the entire semester. The above research is validated by implementing the revised methodology in the course Data Structures and Algorithms (DSA). The research outperforms the in results by Course Outcome attainment analysis.
\end{abstract}

Keywords-Course Outcomes, CO, OBEE, SMART

\section{INTRODUCTION}

According to Alfie Kohn, Learning is something students do, NOT something done to students [1]. Teaching-learning pedagogy is an essential aspect of the current education system. With the current trend of a student, it is very important to define the course outcome before the actual delivery of a course. According to the guidelines defined in previous research [4], the current paper is based on OBEE architecture. As per the research it has 5 layer, where the first layer is build layer. This implements the course outcomes of a particular course.

There is research happened on how to make innovative course outcomes which are cited in [12, 13, 14, 15, 16, 17]. The structured course outcomes help to shape teachinglearning shape properly. It also helps the instructor to define assessment tools that are suitable for the course.

The Outcome-Based Education (OBE) defines the course outcomes based on blooms taxonomy. It has some action words according to some level. There are majorly five levels viz. remember, understand, apply, analyze, evaluate and create. Remember is very basic and level 1 taxonomy whereas create is level 5 and highest taxonomy of bloom.

Revised Manuscript Received on July 22, 2019.

Kamal Mistry, Computer Engineering Department, Mukesh Patel School of Technology Management and Engineering, NMIMS University, Mumbai, India,kamal.mistry@nmims.edu

Prathamesh Churi, Computer Engineering Department, Mukesh Patel School of Technology Management and Engineering, NMIMS University, Mumbai, India, Prathamesh.churi@nmims.edu
There are certain problems of course outcomes through several kinds of the research cited in [18, 19, and 20]. The current method is adopting the S.M.A.R.T. approach to making course outcomes through three meets. The involvement of stakeholders like teachers, domain experts, industrialist, alumni students helps to make course outcome more fruitful.

The details of the three meets are as follows.

- In the $1^{\text {st }}$ meet, the course teacher makes a list out all the lesson outcomes. Lesson outcome should be equal to the number of the chapter in that course.

- In the $2^{\text {nd }}$ meet, an expert should be included where the discussion should be done on the $\mathrm{CO}$ developed by the course teacher. The domain expert will evaluate the $\mathrm{CO}$ whether they are developed as per the S.M.A.R.T approach which is explained in further sections of this paper.

- In the $3^{\text {rd }}$ meet, expert meets the Industrial professional and they will together discuss the course outcome whether they are meeting the industrial needs. An industry expert will check whether the CO's which are developed are more practical and application oriented.

The finalized course outcomes are then subjected to attainment which is a regular requirement of most of the national/international accreditation process $[21,22,23$, and 24]. The results show the revised course attainment analysis through various assessment tools that are used in the course.

For the results, Data Structure and Algorithm (DSA) course is taken into consideration. DSA is the course for the MBA in Technology Management Program at School of Engineering, NMIMS University. The strength capacity of the students is 60. The suggested methodology outperforms through various assessment tools which are defined in section V.

\section{EXISTING SYSTEM}

There are many approaches to the development of the course outcome. Few of them are listed

\section{A. Random Approach}

In this method, an academic committee of faculties is assigned for the development of course outcomes irrespective of the individual's area of interest. As the faculty committee may/may not the domain expert, developed $\mathrm{CO}$ will not be useful and functional. The problem associated with the casual approach is that the CO's which are designed by the committee may/may not be developed in a group. In general case, it 
happens that the development of a few subject outcomes is assigned to an individual. Based on his/her best knowledge, the Cos is developed which may not be effective in every case. The committee also sticks to the syllabus/curriculum defined by institute /university. In such case, if a program is not proper then the CO's which are developed for the particulate subject may not be appropriate or functional to assess the knowledge of a student.

"Engineering and Technology are two of the most relevant fields in any modern society because engineered products and smart systems advance the quality of life and the welfare of people. Thus, providing quality education to the next generation of engineers will enable employability and contribution to the nation's development [2]. Engineering CO's are developed to impart Engineering knowledge. It means that $\mathrm{CO}$ which are generated for a particular subject must have a taste of Industrial Experiences and practices. The $\mathrm{CO}$ should directly reflect the application /contribution of engineering subject towards the industry. Due to Time constraints, academic pressure and wrongly designed curriculum the $\mathrm{CO}$ may be incorrectly designed.

\section{B. Blooms Taxonomy [10, 11]}

In 1956, Benjamin Bloom published a for categorizing educational goals: Taxonomy of Educational Objectives [3]. Bloom's taxonomy is widely used in many recognized university for the development of Course Outcomes.

The entire framework has 6 pillars: Knowledge, Comprehension, Application, Analysis, Synthesis, and Evaluation. The categories after Knowledge were presented as "skills and abilities," with the understanding that knowledge was the necessary precondition for putting these skills and abilities into practice [3]

In this approach, the sample lesson outcomes are formed by individual faculty (preferably from the domain expert). More than 2 lesson outcomes are combined for the development of individual course outcome. The problem associated with the system is that blooms taxonomy does not give guidelines for industry-academic relations. Many of faculty sometimes are not adhere to the blooms taxonomy. The blooms taxonomy also sticks to the traditional keywords. The poorly designed syllabus does not match with any of the keywords. Faculty do not have knowledge of blooms taxonomy its working and methodology.

\section{Bloom's Taxonomy}

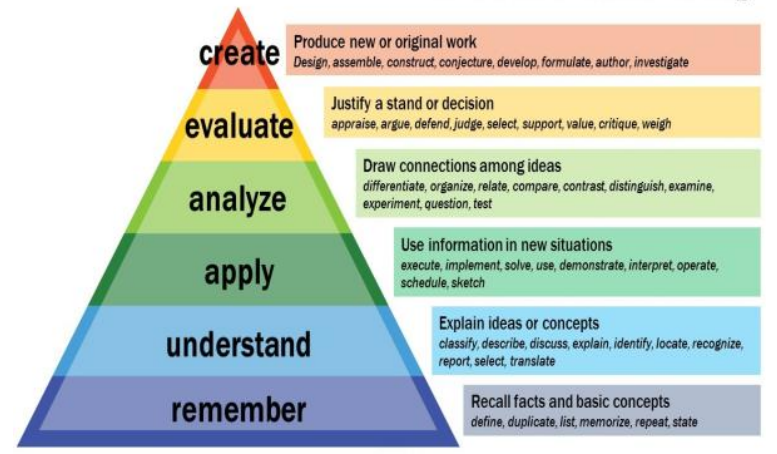

Fig. 1. Blooms Taxonomy Triangle

\section{METHODOLOGY}

In this section, we are going to discuss the development of the Course outcome based on the Build Layer of the Outcome Based Engineering Education (OBEE) Architecture[4].

In this section, we are going to discuss the innovative approach of designing course outcomes based on Build Layer of Outcome-Based Engineering Education (OBEE) Architecture [4].

\section{A. Build a layer of OBEE}

Build layer is used for the development of the course outcome for all the courses based on the lesson outcomes. Lesson outcomes will be equivalent to the number of a chapter that course comprised of and based on that we can develop Course Outcome using S.M.A.R.T approach. S.M.A.R.T approach uses the team for the development of Course Outcome. The team consists of Course teacher, Course Expert, Alumni, and Industry person.

\section{B. Course Teacher}

Course teacher is the properly authorized individual to design $\mathrm{CO}$ for his/her course as he/she may be teaching that particular course/subject for multiple so he/she can design CO which are effective and attainable theoretically as well as practically. Initially, develop a lesson outcome of every chapter in that course and based on that $\mathrm{CO}$ can be developed. 2 or 3 lesson outcome can be clubbed together to form one course outcome depending on the detailing of the individual chapters. A meeting should be conducted with the other faculties/teacher teaching the same subject in the different division or had taught the particular subject in the previous academic year. Based on the discussion we can again modify/reconstruct the $\mathrm{CO}$.

After the reconstruction of the course, outcome finalizes and inform students who are going to study that course.

After reframing of course outcomes finalize it and convey to the students in the very first lecture about the same.

\section{Alumni}

Alumni are a group of students who are graduated and working In INDUSTRY or in the Education sector. Alumni are assets to any institution.

Alumni are the students who had already passed out and working in the IT industry or any teaching firm. They are the one who had already studied this particular course so they can share their problems which they had faced while attaining $\mathrm{CO}$ of the respective course. Their feedback should be taken into consideration so that the students who will study that particular course/subject should not face the same problem. Their feedback also helps School/colleges to develop CO which are feasible and achievable for faculties as well as for students.

\section{Subject Expert}

Subject expert is the person who had been teaching this particular subject since 5 or more years. The subject expert takes all the points into consideration which are given by 
course teacher and alumni for the development of CO. He is the expertise of that course so he may know the difficulties which students might face while studying the course. So he will segregate everything and develop Course Outcome which will be feasible to attain for course teacher as well as students.

\section{E. Industry Professional:}

Gives the proper guidelines in the development of the $\mathrm{CO}$ as per the current industrial trend. He will ensure that application oriented things are included so that it will be beneficial for the students to understand real-time application for what they are studying. CO should be equally balanced theoretically as well as a practice which meets the current IT trend and it should also include the usage of latest tools and technologies.

The panel will finalize the course objectives/outcomes using S.M.A.R.T [5] approach. The development of course objective outcomes is a pre-semester activity. It means that it should commence before the actual course begins. There must be at least 3 minutes of the meeting which has to be conducted by the course teacher. The actions are listed below:

Using S.M.A.R.T.[5] approach panel can finalize the outcomes for courses. Course outcome development is an activity which needs to be done prior semester commences. 3 Meetings should be conducted by the course teacher. The action is listed below:

\section{- 1st Meet:}

Course teacher should list out all the lesson outcomes. Lesson outcome should be equal to the number of the chapter in that course. All the subtopics must be properly described in the lesson outcome. Depending on the depth of the individual chapters and weight age the CO must be developed. Segregate 2 or more lesson outcomes together to form a Single CO but while segregating make ensure that chapters are interrelated or have some continuity. After designing $\mathrm{CO}$ for the particular Course conduct the meeting with the other course teacher who is teaching that subject for another division and then both the course teacher should be ready with the COURSE OUTCOME for their course before the second meet.

\section{- 2nd Meet:}

In this meet domain, an expert should be included where the discussion should be done on the $\mathrm{CO}$ developed by the course teacher. The domain expert will evaluate the $\mathrm{CO}$ whether they are developed as per the S.M.A.R.T approach. $\mathrm{He} / \mathrm{she}$ may/may not modify the $\mathrm{CO}$ as per his/her experience. Meeting with the domain expert is beneficial because they will verify that CO's are developed as per Bloom's taxonomy.

\section{- 3rd Meet;}

In this meet domain, expert meets the Industrial professional and they will together discuss the COURSE OUTCOME whether they are meeting the industrial needs. An industry expert will check whether the CO's which are developed are more practical and application oriented. In this meet the feedback given from the alumni will also be taken into consideration because they are the one who had already studied that particular course and they might have suggested something which needs to be given priority while developing CO. COURSE OUTCOME will be finalized in this meeting with the help of inputs given from industry expert, alumni, domain expert, and Course teacher. So the final COURSE OUTCOME which will be developed will be S.M.A.R.T.

S.M.A.R.T stands for (Specific Measurable Achievable Realistic Time Bound)

\section{- Specific:}

Every $\mathrm{CO}$ must be specific and crisp. After reading that $\mathrm{CO}$ individual should be able to understand that it's mapped to which chapters of that particular course. It must be simple so that students also understand whatever they are studying are related to which course outcomes. It will be easier for the course teacher to attain the $\mathrm{CO}$ practically as well theoretically.

\section{- Measurable}

The CO which is developed must be measurable using the various assessment tool. It is always a good practice if a course teacher decides assessment tools prior to content delivery. After the completion of a particular course, outcome faculty should be able to assess students. Ultimately students are the one whom we are going to measure whether they passed or failed in that particular CO. So CO shouldn't be vague that it cannot be measured so such $\mathrm{CO}$ statements will be meaningless.

\section{- Achievable and Realistic}

The course outcome which is developed should be achievable within specific constraints of a course. Sometimes it happens that a particular topic of a course consumes a lot of time with respect to its delivery and assessment.

Understanding, assessing and evaluating. Such kind of course outcome may be difficult to achieve. Therefore it's always the good practice if we divide particular course outcomes into more outcomes.

\section{- Timely bound}

Specific time bound should be given to each course outcome. We must not design such course objective/outcome which consumes a lot of time to understand, assess and evaluate. Course outcomes should not be designed in such a way which consumes time in the evaluation process. Proper development of the timeline chart for completion of course outcome with its assessment is the solution to achieve this criterion [4]. TimeLine chart is the solution to achieve this criterion.

As stated, we need to assess the course outcomes that we have designed. We need to prepare the S.M.A.R.T table (Table I) [ ref PC] and should be distributed to the panel in the 3rd meet. The S.M.A.R.T table needs to be prepared and circulated among the panel member in the $3^{\text {rd }}$ meet. Consider the course outcomes that you have developed (limit the outcomes to maximum 4 to 5 ). List your outcomes in a table similar to the one below and rank if your targets meet the requirements of each parameter of S.M.A.R.T outcomes. The 
rank should be from minimum 1 to 5 where 5 is excellently designed,4 Good, 3- Average 2- below a threshold, 1 - poor. Each member of the panel must be given a SMART table sheet. For each course outcome, the average rank given by all members should be above 3 . We must record this figure as we need this rank later on in the feedback layer of OBEE model.

TABLE I. SAMPLE SMART TABLE

\begin{tabular}{|c|l|l|l|l|l|}
\hline $\begin{array}{c}\text { Course } \\
\text { Outcomes }\end{array}$ & Specific & Measurable & Achievable & Realistic & $\begin{array}{c}\text { Time } \\
\text { Bound }\end{array}$ \\
\hline CO1 & & & & & \\
\hline CO2 & & & & & \\
\hline CO3 & & & & & \\
\hline CO4 & & & & & \\
\hline CO5 & & & & & \\
\hline
\end{tabular}

\section{RESULTS}

We are considering the course Data Structures \& Algorithms as a case study. The total duration of completion, of course, is 45 hours. The detailed syllabus is shown in fig 1 below. There are total 8 units out of which unit 1, 3, 4 belongs to a sub-course data structure and unit 2,5,6,7,8 belongs to an analysis of the algorithm.

\begin{tabular}{|c|c|c|}
\hline \multicolumn{3}{|c|}{ Detailed Syllabus: } \\
\hline Unit & Description & Duration \\
\hline 1. & $\begin{array}{l}\text { Data Structures: Linked List - Single, Double, Circular; Stacks-Infix, } \\
\text { Postfix, Prefix; Queues-Circular, Priority Queue, Deque ; Trees-Binary } \\
\text { Tree, and Graphs. }\end{array}$ & 10 \\
\hline 2. & $\begin{array}{l}\text { Analyzing the Algorithms: Introduction to Complexity Theory, Time } \\
\text { and Space Complexity, Lower bounds and the complexity of problems, } \\
\text { Classifying functions by their asymptotic growth rates, Different study } \\
\text { area's in algorithm, Asymptotic notations, Asymptotic order, } \\
\text { Properties of big oh, big omega, and big theta, Asymptotic order of } \\
\text { common problems, Best case, average case and worst case analysis for } \\
\text { common problems, Optimality. }\end{array}$ & 4 \\
\hline 3. & $\begin{array}{l}\text { Basic Search and Traversal Techniques for: Binary tree traversal:- In- } \\
\text { order, Preorder and Post-order tree traversal. Search and traversal } \\
\text { techniques for graphs - BFS, DFS. }\end{array}$ & 4 \\
\hline 4. & $\begin{array}{l}\text { Searching and Sorting Techniques: Efficiency considerations in } \\
\text { searching, Basic Searching Techniques- Sequential search, Searching } \\
\text { ordered table, Indexed sequential search, Binary search, Interpolation } \\
\text { search, Binary search tree, Hashing. Efficiency considerations in sorting, } \\
\text { General sorting Methods- Bubble sort, Binary tree sort, Heaps and Heap } \\
\text { sort, Heap as Priority queues, Shell sort, Bucket sort, Radix sort. Time }\end{array}$ & 7 \\
\hline & $\begin{array}{l}\text { complexity calculations, Best case, worst case and average case } \\
\text { calculations of the different sorting methods. }\end{array}$ & \\
\hline 5. & $\begin{array}{l}\text { Divide and Conquer Technique: The general method, control } \\
\text { abstraction for divide and conquer, Iterative form of divide and conquer } \\
\text { control abstraction, Merge sort, Insertion sort, Quick sort, Selection sort, } \\
\text { Time complexity calculations, Best case, worst case and average case } \\
\text { calculations of the different sorting methods. }\end{array}$ & 5 \\
\hline 6. & $\begin{array}{l}\text { Greedy Technique: The general method, Knapsack problem, Minimum } \\
\text { spanning trees, Prim's and Kruskal's algorithm, Single source shortest } \\
\text { paths algorithm. }\end{array}$ & 5 \\
\hline 7. & $\begin{array}{l}\text { Dynamic Programming: The general method, principle of optimality, } \\
\text { All pairs shortest paths, Optimal binary search trees, } 0 / 1-\mathrm{knapsack} \text {. }\end{array}$ & 5 \\
\hline 8. & $\begin{array}{l}\text { Backtracking: The general method, Estimating the efficiency of } \\
\text { backtracking, The Tic-Tac-Toe problem, Knapsack problem. }\end{array}$ & 5 \\
\hline
\end{tabular}

Fig. 2. Syllabus of Data Structure \& algorithms

According to the suggested research, the minutes of meetings( 3 meetings) are conducted. The inputs from alumni and Industry expert are recorded. The details of individual minutes of the meeting are given in the table below.
TABLE II. MINUTES OF MEETINGS FOR CO-DEVELOPMENT

\begin{tabular}{|c|c|c|}
\hline Meet & $\begin{array}{l}\text { Involved } \\
\text { Users }\end{array}$ & Minutes of meeting \\
\hline $\mathrm{I}$ & $\begin{array}{l}\text { Course } \\
\text { Teacher/s } \\
\text { Domain Expert }\end{array}$ & 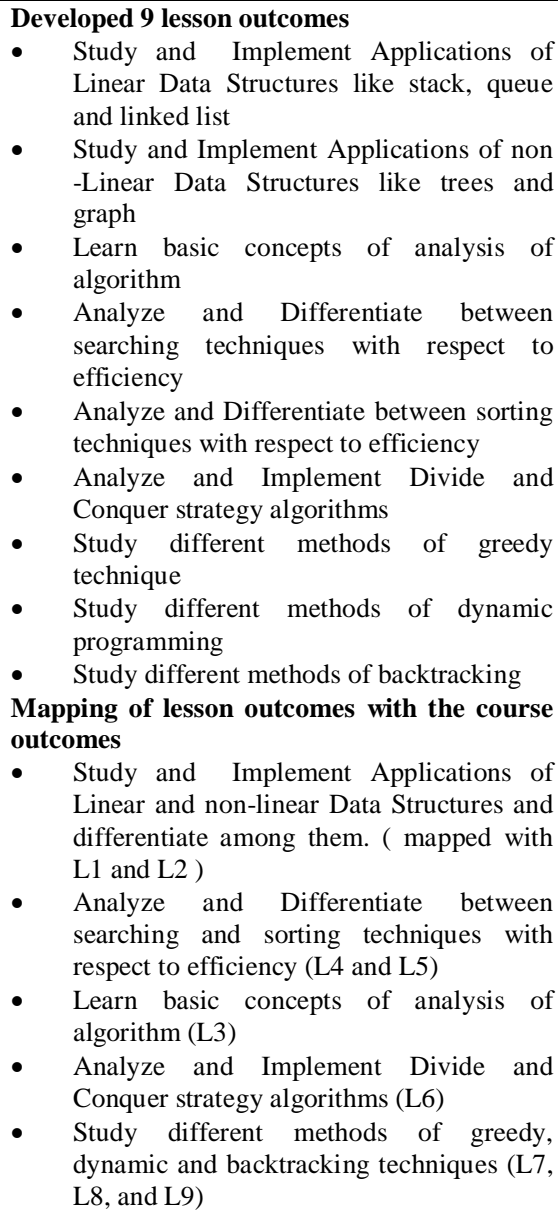 \\
\hline II & $\begin{array}{l}\text { Course } \\
\text { Teacher/s } \\
\text { Domain Expert } \\
\text { Alumni }\end{array}$ & $\begin{array}{l}\text { - The problem with the algorithmic } \\
\text { strategies is that students were not able to } \\
\text { differentiate among all the strategies which } \\
\text { they learned. we have got feedback from } \\
\text { the alumni students about the same. } \\
\text { In order to improve the previous course } \\
\text { outcomes, there must be a refinement of } \\
\text { Course Outcomes with the consideration } \\
\text { of suggestion given by alumni. The list of } \\
\text { CO is given below. } \\
\text { Study and Implement Applications of } \\
\text { Linear and nonlinear Data Structures and } \\
\text { differentiate among them. ( mapped with } \\
\text { L1 and L2) } \\
\text { Analyze and Differentiate between } \\
\text { searching and sorting techniques with } \\
\text { respect to efficiency (L4 and L5) } \\
\text { Learn basic concepts of analysis of } \\
\text { algorithm (L3) } \\
\text { Analyze and Implement Divide and } \\
\text { Conquer strategy algorithms (L6) } \\
\text { Compare and Contrast different methods } \\
\text { of greedy, dynamic and backtracking } \\
\text { techniques (L7, L8, and L9) }\end{array}$ \\
\hline
\end{tabular}




\begin{tabular}{|l|l|l|}
\hline III & $\begin{array}{l}\text { Course } \\
\text { Teacher/s } \\
\text { Domain Expert } \\
\text { Alumni } \\
\text { Industry } \\
\text { Expert }\end{array}$ & $\begin{array}{l}\text { The course outcomes which are formed } \\
\text { does not explain the contribution of a } \\
\text { subject in the industry. students may not } \\
\text { able to map the chapters and their } \\
\text { application in industry point of view. }\end{array}$ \\
& $\begin{array}{l}\text { The revised CO with the suggestion of } \\
\text { Industry Expert is given below: } \\
\text { Classify Linear and non-linear Data } \\
\text { Structures and Implement its applications } \\
\text { Analyze and Differentiate between } \\
\text { searching and sorting techniques with } \\
\text { respect to efficiency } \\
\text { Discuss Complexity Theory for analysis of } \\
\text { algorithm } \\
\text { Compare and Contrast different algorithm } \\
\text { design strategies } \\
\text { Formulate a problem and Develop an } \\
\text { algorithmic strategy for a case study. } \\
\text { SMART table sheet is distributed among } \\
\text { all the members of the panel. The course } \\
\text { outcomes are tested according to SMART } \\
\text { guidelines. }\end{array}$ \\
\hline
\end{tabular}

\section{RESULTS AND DISCUSSIONS}

In order to provide fruitful evidence, we have documented the assessment of individuals after reframing the course outcomes according to the SMART approach. The assessment methods are as follows:

- Term Tests - Total three term test of 15 marks each is taken. Third term test is considered as an improvement test over the first two tests.

- Laboratory works - Total 10 experiments are taken in the entire duration of course work. Each experiment maps with the corresponding CO's for attainment calculation later on.

- Assignments- written assignments are purely analytical and case study based. Minimum 2 assignments are taken from each student.

- Practical Exam - Practical exam is taken in order to check the practical knowledge of the subject.

All the assessment tools are considered as compulsory for all the students. Table III, IV, V. VI has given course outcome attainment $[6,7,8,9]$.

TABLE III. COURSE OUtCome ATtAinMENT OF TERm Test I, II, III (CONSOLIDATED)

\begin{tabular}{|c|l|l|l|l|l|}
\hline Course Outcomes & CO 1 & CO 2 & CO 3 & CO 4 & CO 5 \\
\hline $\begin{array}{c}\text { Total Number of } \\
\text { Student Appeared for } \\
\text { exam }\end{array}$ & \multicolumn{5}{|c|}{68} \\
\hline $\begin{array}{c}\text { Total Number of } \\
\text { Students passed the } \\
\text { exam ( 60\% } \\
\text { attainment level) }\end{array}$ & 47 & 57 & 61 & 58 & 55 \\
\hline \% of Attainment & 69.11 & 83.82 & 89.70 & 85.29 & 80.88 \\
\hline
\end{tabular}

TABLE IV. COURSE OUTCOME ATtAINMENT THROUGH ASSIGNMENTS

\begin{tabular}{|c|c|c|c|c|c|}
\hline Course Outcomes & CO 1 & $\mathrm{CO} 2$ & $\mathrm{CO} 3$ & $\mathrm{CO} 4$ & CO 5 \\
\hline Assignment & \multicolumn{2}{|c|}{ I } & \multicolumn{3}{|c|}{ II } \\
\hline $\begin{array}{c}\text { Total Number of } \\
\text { Student Appeared for } \\
\text { exam }\end{array}$ & \multicolumn{5}{|c|}{68} \\
\hline $\begin{array}{c}\text { Total Number of } \\
\text { Students passed the } \\
\text { exam ( } 60 \% \\
\text { attainment level) }\end{array}$ & 31 & 51 & 57 & 57 & 61 \\
\hline$\%$ of Attainment & 45.58 & 75.00 & 83.82 & 83.82 & 89.70 \\
\hline
\end{tabular}

TABLE V. COURSE OUTCOME ATtAINMENT THROUGH LABORATORY WORK

\begin{tabular}{|c|l|l|l|l|l|}
\hline Course Outcomes & CO 1 & CO 2 & CO 3 & CO 4 & CO 5 \\
\hline $\begin{array}{c}\text { Total Number of } \\
\text { Student Appeared for } \\
\text { Lab work }\end{array}$ & \multicolumn{5}{|l|}{68} \\
\hline $\begin{array}{c}\text { Total Number of } \\
\text { Students passed the } \\
\text { exam ( 60\% } \\
\text { attainment level) }\end{array}$ & 57 & 56 & 61 & 64 & 50 \\
\hline \% of Attainment & 83.82 & 82.35 & 89.70 & 94.11 & 73.52 \\
\hline
\end{tabular}

TABLE VI. COURSE ATTAINMENT THROUGH LABORATORY EXAM

\begin{tabular}{|c|l|l|l|l|l|}
\hline Course Outcomes & CO 1 & CO 2 & CO 3 & CO 4 & CO 5 \\
\hline $\begin{array}{c}\text { Total Number of } \\
\text { Student Appeared for } \\
\text { exam }\end{array}$ & \multicolumn{5}{|l|}{} \\
\hline $\begin{array}{c}\text { Total Number of } \\
\text { Students passed the } \\
\text { exam ( 60\% } \\
\text { attainment level) }\end{array}$ & 41 & 48 & 46 & 51 & 54 \\
\hline \% of Attainment & 60.29 & 70.58 & 67.64 & 75.00 & 79.41 \\
\hline
\end{tabular}

TABLE VII. COURSE ATtAINMENT THOUGH COURSE EXIT SURVEY

\begin{tabular}{|c|l|l|l|l|l|}
\hline Course Outcomes & CO 1 & CO 2 & CO 3 & CO 4 & CO 5 \\
\hline $\begin{array}{c}\text { Total Number of } \\
\text { students participated } \\
\text { in the online course } \\
\text { exit survey }\end{array}$ & \multicolumn{5}{|l|}{6} \\
\hline $\begin{array}{c}\text { Total Number of } \\
\text { Students who have } \\
\text { given 3 and 4 rating } \\
\text { out 4 }\end{array}$ & 57 & 51 & 50 & 58 & 61 \\
\hline \% of Attainment & 83.82 & 75.00 & 73.52 & 85.29 & 89.70 \\
\hline
\end{tabular}

The consolidated Course Outcome attainment through various assessment level is calculated from table III, IV, V, VI and is tabulated in Table VIII

TABLE VIII. CONSOLIDATED CO ATTAINMENT FOR DSA COURSE.

\begin{tabular}{|c|c|c|c|c|c|}
\hline Course Outcomes & CO 1 & CO 2 & CO 3 & CO 4 & CO 5 \\
\hline Term Test & 69.11 & 83.82 & 89.70 & 85.29 & 80.88 \\
\hline Assignments & 45.58 & 75.00 & 83.82 & 83.82 & 89.70 \\
\hline Laboratory Work & 83.82 & 82.35 & 89.70 & 94.11 & 73.52 \\
\hline Laboratory Exam & 60.29 & 70.58 & 67.64 & 75.00 & 79.41 \\
\hline Course Exit Survey & 83.82 & 75.00 & 73.52 & 85.29 & 89.70 \\
\hline $\begin{array}{c}\text { Average CO } \\
\text { Attainment }\end{array}$ & $\mathbf{6 8 . 5 2}$ & $\mathbf{7 7 . 3 5}$ & $\mathbf{8 0 . 9 7}$ & $\mathbf{8 4 . 7 0}$ & $\mathbf{8 2 . 6 4}$ \\
\hline
\end{tabular}




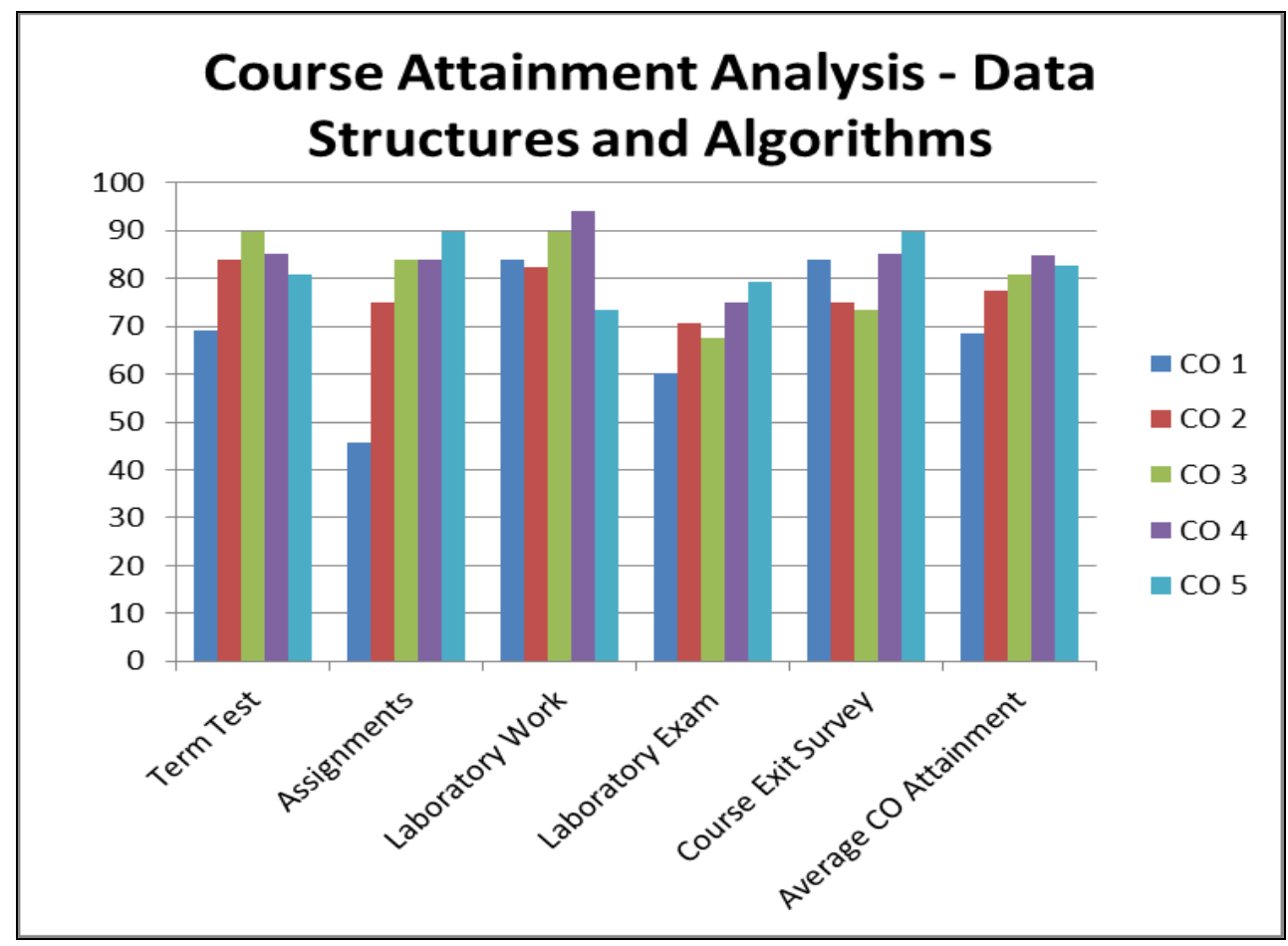

Fig. 3. Course Attainment Analysis - Data Structures and Algorithms

\section{CONCLUSION}

The existing system of developing course outcome was the unstructured process. The current system involves domain expert who structures the course outcomes developed by the course teacher. The system also involves alumni to add experience in learning the course. Industry professional shapes the outcomes according to industry trends. The research also focuses on the SMART approach for developing course outcome which ensures that the developed CO are Specific, Measurable, Achievable, Realistic and Time-bound.

The future scope of this system may include the use of technology while developing the course outcomes. The use of an artificial intelligence algorithm may use to create Course Outcomes. An automated system of developing course outcomes may be fruitful which has less interference of human.

\section{REFERENCES}

[1] Alfie Kohn, "It's Not What We Teach; It's What They Learn", Website: http://www.alfiekohn.org/article/teach-learn/ , Last Accessed: January 16,2017

[2] A. Pears, "Assuring the Quality of Engineering Education," 2015 International Conference on Learning and Teaching in Computing and Engineering, Taipei, 2015, pp. 108-111.

[3] Huitt, William. "Bloom et al.'s taxonomy of the cognitive domain." Educational psychology interactive 22 (2004).

[4] Churi, P., Mistry, K., Dhruv, A., \& Wagh, S. (2016, December). Alchemizing Education System by Developing 5 Layered Outcome
Based Engineering Education (OBEE) Model. In 2016 IEEE 4th International Conference on MOOCs, Innovation, and Technology in Education (MITE) (pp. 338-345). IEEE.

[5] SMART targets in project management, website: http://www.contentextra.com/eet/files/topicguides/topic-guide34.2smarttargets-in-project-management.pdf , Last accessed: August 14, 2016

[6] Abidin, I. Z., Anuar, A., \& Shuaib, N. H. (2009). Assessing the attainment of course outcomes (CO) for an engineering course. In International Conference of Teaching and Learning (ICTL 2009) INTI University College, Malaysia.

[7] Farnier, M., Volpe, M., Massaad, R., Davies, M. J., \& Allen, C. (2005) Effect of co-administering ezetimibe with on-going simvastatin treatment on LDL-C goal attainment in hypercholesterolemic patients with coronary heart disease. International journal of cardiology, 102(2), 327-332.

[8] Harp, G. D., Miller, J. M., \& Berne, B. J. (1968). Attainment of statistical equilibrium in excited nuclei. Physical Review, 165(4), 1166

[9] Enderlin, K. J. (1993). Student achievement, attitudes, and thinking skill attainment in an integrated science/agriculture course.

[10] Krathwohl, D. R. (2002). A revision of Bloom's taxonomy: An overview. Theory into practice, 41(4), 212-218.

[11] Churches, A. (2008). Bloom's taxonomy blooms digitally. Tech \& Learning, 1, 1-6.

[12] Stone, S. L., \& Qualters, D. M. (1998). Course-based assessment: implementing outcome assessment in medical education. Academic medicine: journal of the Association of American Medical Colleges, 73(4), 397-401.

[13] Spady, W. G. (1994). Outcome-Based Education: Critical Issues and Answers. American Association of School Administrators, 1801 North Moore Street, Arlington, VA 22209 (Stock No. 21-00488; \$18.95 plus postage).

[14] Harden, R. M. (1999). AMEE Guide No. 14: Outcome-based education: Part 1-An introduction to outcome-based education. Medical Teacher, 21(1), 7-14 
[15] Felder, R. M., \& Brent, R. (2003). Designing and teaching courses to satisfy the ABET engineering criteria. Journal of Engineering Education, 92(1), 7-25.

[16] Diamond, R. M. (2011). Designing and assessing courses and curricula: A practical guide. John Wiley \& Sons.

[17] Qualters, D. M., Sheahan, T. C., Mason, E. J., Navick, D. S., \& Dixon, M. (2008). Improving Learning in First-Year Engineering Courses through Interdisciplinary Collaborative Assessment. Journal of Engineering Education, 97(1), 37-45.

[18] Davis, D., Beyerlein, S., Thompson, P., Gentili, K., \& McKenzie, L. (2003, June). How universal are capstone design course outcomes? In Proc. 2003 Am. Soc. Eng. Educ. Ann. Conf. \& Exposition (pp. 22-25), Washington^ EDC DC: American Society for Engineering Education

[19] Gültekin, M. (2005). The Effect of Project Based Learning on Learning Outcomes in the 5th Grade Social Studies Course in Primary Education. Educational Sciences: Theory \& Practice, 5(2).

[20] Drew, S. (1998). Students' perceptions of their learning outcomes. Teaching in Higher Education, 3(2), 197-217.

[21] Eaton, J. S. (2006). An overview of US accreditation. Council for Higher Education Accreditation.

[22] Ng, K. B., Leung, G. K., Johnston, J. M., \& Cowling, B. J. (2013). Factors affecting the implementation of accreditation programs and the impact of the accreditation process on quality improvement in hospitals: a SWOT analysis. Hong Kong Medical Journal.

[23] Patil, A., \& Codner, G. (2007). Accreditation of engineering education: review, observations, and proposal for global accreditation. European journal of engineering education, 32(6), 639-651.

[24] Jantzen, R. H. (2000). AACSB mission-linked standards: Effects on the accreditation process. Journal of Education for Business, 75(6), 343347. 